九州大学学術情報リポジトリ

Kyushu University Institutional Repository

\title{
On Three New Species Of Galathea From The Western Pacific
}

Miyake, Sadayoshi

Zoological Laboratory, Department of Agriculture, Kyushu University

https://doi.org/10.5109/22654

出版情報：九州大学大学院農学研究院紀要. 10 (2)，pp. 199-208，1953-09. Kyushu University バージョン：

権利関係: 


\section{ON THREE NEW SPECIES OF GALATHEA FROM THE WESTERN PACIFIC ${ }^{1)}$}

\section{SADAYOSHi MryaKe}

The Galatheids dealt with in this paper are all preserved in the collection of the Zoological Laboratory, Faculty of Agriculture, Kyushu University. I wish to express my hearty thanks to Prof. Dr. Y. K. Hiraiwa, Zoological Laboratory, Faculty of. Agriculture, Kyushu University, who has provided me with facilities required for the pursuit of this work. I am especially indebted to Dr. H. Ohshima, M. J.A., for giving me the opportunity to study the material collected in his expeditions.

\section{Galathea biunguiculata sp. nov.}

Text-fig. 1-2.

The carapace is rather depressed and the upper surface is furnished with squamiform scales beneath tomentum. The rostrum is equipped with four teeth on each lateral margin. Lateral margins of the carapace are equipped with six teeth: the first tooth is smallest of all; the second is largest; succeeding ones decrease in size posteriorly. There are two small teeth on the gastric region.

The sternum of the third maxilliped is very broad, of a triangular shape, with a small but prominent sinus at the tip. The sternum of chelipeds diverges posteriorly, its lateral margins being almost straight. The first peduncle of the antennule bears three spines: the inner and the outer spines are furnished with long hairs; the second peduncle of the antenna bears an acuminate spine on each inner and outer angle; the merus of the third

1) Contributions from the Zoological Laboratory, Faculty of Agriculture, Kyushu University, No, 207. 
maxilliped is equipped with two teeth on the inner margin, but is toothless on the outer margin.

The chelipeds are slightly depressed, 1.5 times as long as the length of carapace and furnished with long hairs along the inner

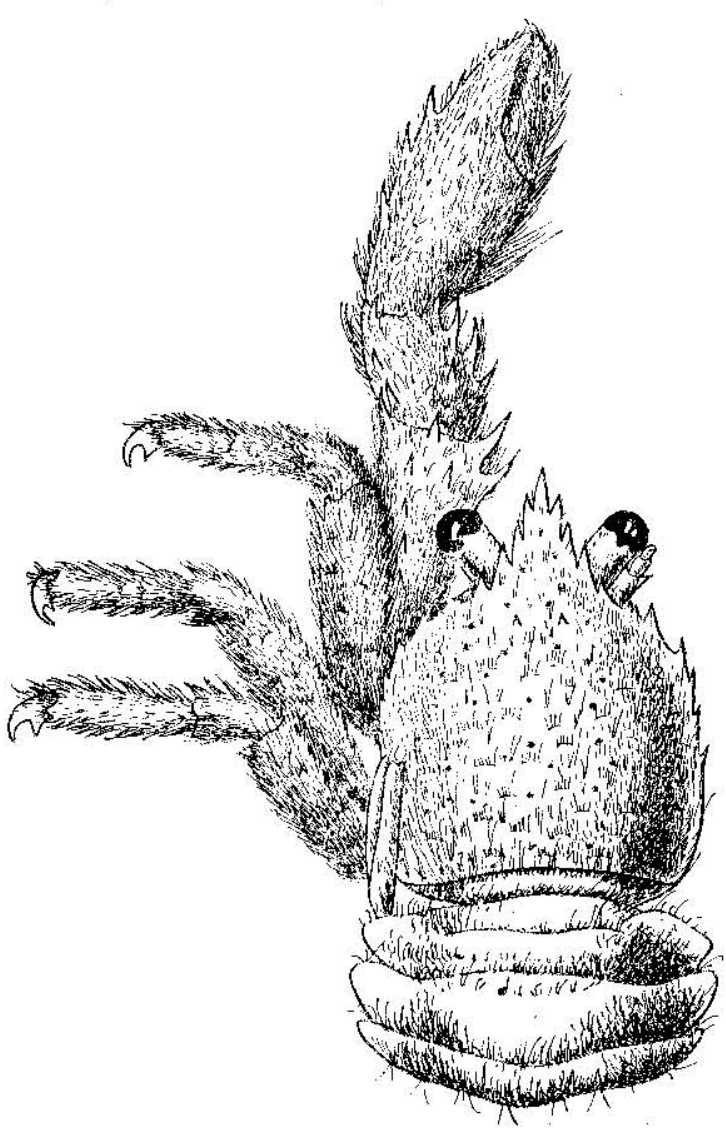

Fig. 1. Galathea biunguiculata sp. nov.

Holotype (ovigerous of) from Palau Islands, $\times 10$.

and outer margins. The arm is provided with two prominent tceth on inner distal end and a row of five spines runs on the upper surface. There is a prominent tooth at the outer extremity of the arm. The wrist is a little shorter than half the palm, the inner margin being equipped with four teeth, the outer margin 
with three. The palm is broad, provided with five spines near the inner margin; in addition to them there are eight teeth on the outer margin. Fingers are furnished with small teeth and pubescent on cutting margins.

The ambulatory legs are depressed, being furnished with long hairs along the antexior and posterior margins. The merus is furnished with seven to nine spines on the anterior margin; the posterior margins of the first two pairs are equipped with five to seven teeth, but that of the third pair is toothless. The carpus is equipped with four spines. The propodus is equipped with three spines on the proximal part of the anterior margin and is furnished with three spinules along the inner margin. The dactylus is provided with an accessory claw on the inner margin. There are five spinules on the inner margin in common members of the genus. The dactylus of this species is diminished first four spinules except the distal one. The distal (fifth) spinule is greatly developed into an acuminate tooth, forming an accessory claw.

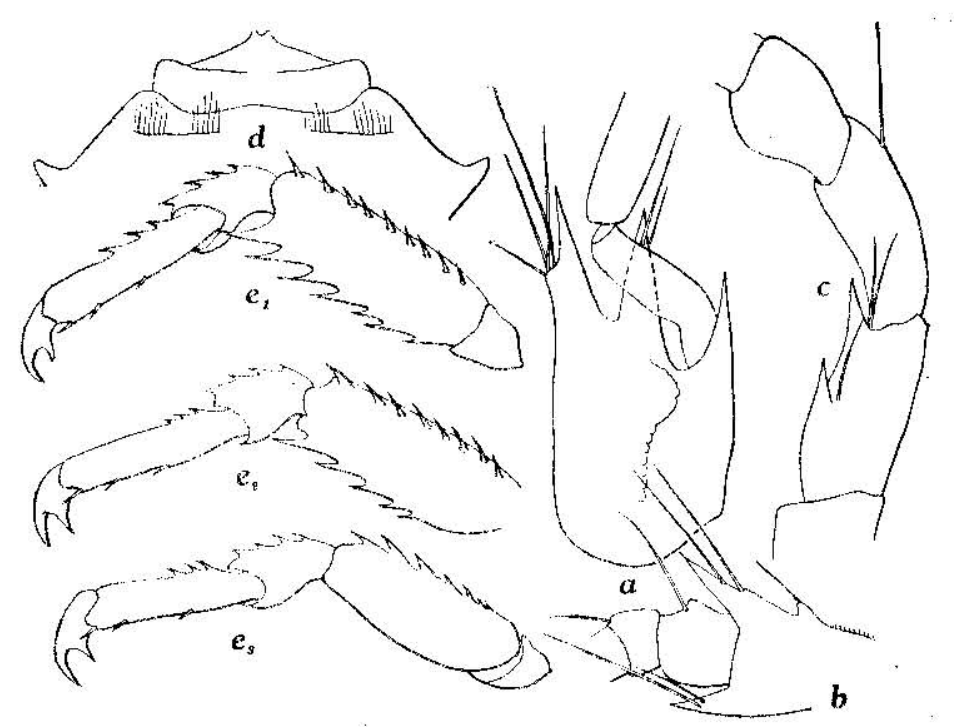

Fig. 2. Galathea biunguiculata $\mathrm{sp}$. nov.

a: First peduncle of left antennule, $\times 40$, b: Basal peduncles of left antenna, $\times 40, \mathrm{c}$ : Third maxilliped of left side, $\times 40, \mathrm{~d}$ : Sternum of third maxilliped, $\times 25, \quad e_{1}$ : Ambulatory leg of first pair $\times 12$, ez: The same of second pair, $\times 12, e_{3}$ : The same of third pair, $\times 12$. 
It has some resemblance to Galathea gardineri Laurie $^{1)}$ in general appearance, but it is easily distinguished by the armature of the carapace and chelipeds. It is provided with five spines on the inner margin of the merus of the second ambulatory leg instead of no spine as in the case of G. gardineri. These two species differ distinctly from other members of the genus by the characteristic features of the dactylus of ambulatory legs and of the sternum of the cheliped, which is not described by Laurie.

Type: Ovigerous , holotype, Cat. No. 100, Zoological Laboratory, Faculty of Agriculture, Kyushu University, from off Narsmau, Babldáob Island, Palau Is., July 14, 1939, collected by Dr. H. Ohshima and the author.

Habitat: Found on sandy and muddy bottoms $26 \mathrm{~m}$ deep, $134^{\circ} 37^{\prime} 30^{\prime \prime}$ E., $7^{\circ} 44^{\prime} 20^{\prime \prime} \mathrm{N}$.

Dimensions (in $\mathrm{mm}$ ) :

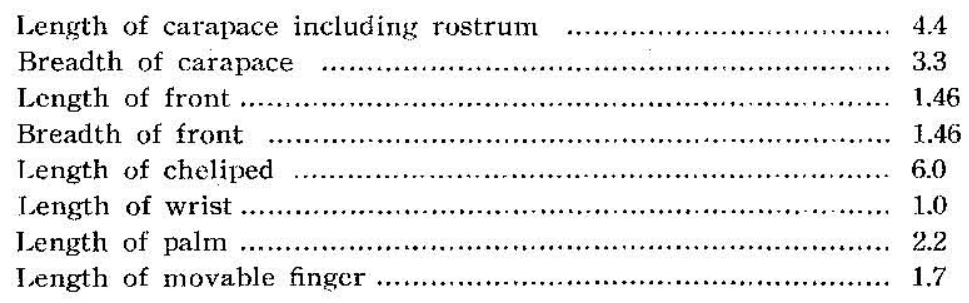

2. Galathea tridentirostris sp. nov.

Text-fig. $3-4$.

The carapace including rostrum is slightly longer than broad; the upper surface is smooth and spinulose: The gastric region is more or less elevated, but is not separated by cervical groove, which is not distinct. The striations of the carapace are ten in number. The rostrum is rather broad, with three spines on each side. Anterolateral margins are strongly divergent, and posterior margins are parallel behind the second teeth.

The first peduncle of antennule is furnished with three spines. The inner spine, dorsally placed, is very small; an another inner spine, ventrally placed and the outer spine are rather broad and equal in length. The first peduncle of antenna is very broad, its

1) Laurie, R. D. 1926 Trans. Linn. Soc., London, Ser. 2, Zool., 19 (1) : 131-133, pl. 9, figs. 1-5. 
inner distal angle very protruding, the anterior margin almost straight. The remaining peduncles are cylindrical, smooth and toothless. The anterior margin of the ischium of the third maxilliped is equipped with an acuminate tooth on both inner and outer angles. The merus is a little longer than broad; the inner margin is equipped with a broad tooth, tip pointed; the outer margin bears an acuminate tooth at the distal part. The carpus is almost smooth on the outer margin.

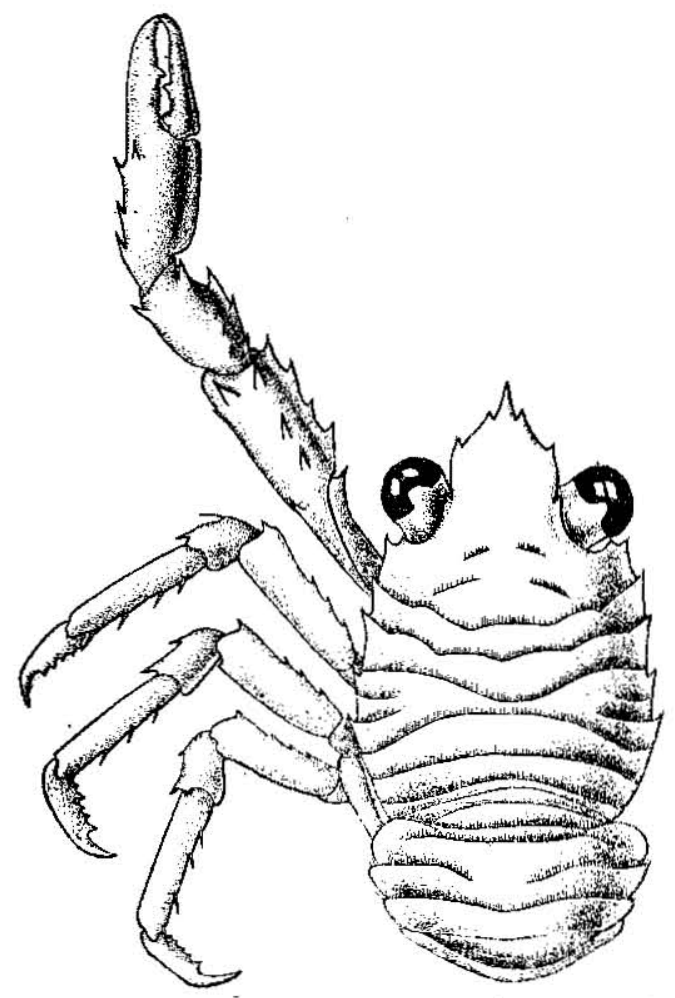

Fig. 3. Galathea tridentirostris sp. nov.

Holotype ( 3 ) from Ishigaki Island, Ryukyu Islands, $\times 16$.

The sternum of the third maxilliped is longer than broad; the lateral margins are almost parallel to each other; the anterior margin is triangular, with the tip rounded and furnished with a scale bearing long hairs at the center of the ventral surface.

The chelipeds are equal in length and twice as long as the carapace including rostrum in both sexes. The ischium bears a 
spine on the inner distal angle. The arm is furnished with three rows of spines; the inner margin is furnished with four spines; the median row, running on the dorsal surface forms three enlarged spines; the outer margin forms two large spines. The wrist is a little shorter than the palm; the inner margin is furnished with four spines, the proximal one being rather small; in addition to them a row of three spines runs near the pronounced marginal spines; there is one spine at the outer distal end. The palm is almost smooth, but for the outer margin, which is equipped with four spines. The cutting margin of movable finger bears two teeth; the one is at the middle and the other is at the proximal end. The cutting margin of the immovable finger bears a tooth near the middle.

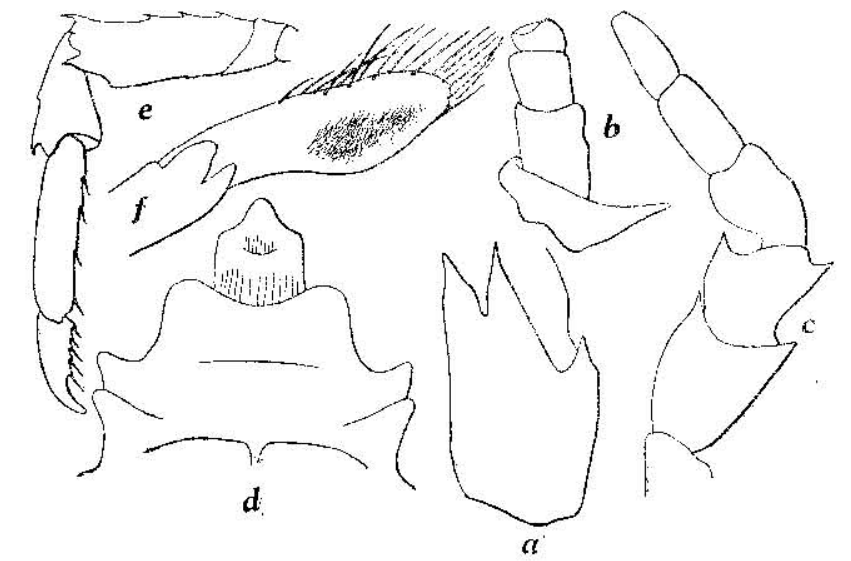

Fig. 4. Galathea tridentirostris sp. nov.

a : First peduncle of left antennule, $\times 40, b$ : Basal peduncles of right antenna, $\times 40, \mathrm{c}$ : Third maxilliped of left side, $\times 40, \mathrm{~d}$ : Sternum of third maxilliped, $\times 25$, e: Second ambulatory leg, $\times 25$, $\mathrm{f}:$ : Abdominal appendage of male, $\times 75$.

The merus of the ambulatory legs is equipped with four spines on the upper margin; the carpus is furnished with one or two spines on upper margin, the distal one being enlarged; the propodus is equipped with four spinules on the posterior margin; the dactylus bears five spinules. Distal peduncle of male abdominal appendage is spoon-shaped.

This species is easily distinguished from the other members 
of the genus by the broad and three-toothed rostrum and the shape of sternum of the third maxilliped.

Types: $\delta$, holotype; ovigerous of, allotype, Cat. No. 105, Zoological Laboratory, Faculty of Agriculture, Kyushu University; 4 to 5,4 ovig. o. , Cat. No. 106, Zool. Lab., Fac. Agr., Kyushu Univ.; from Ishigaki Island, Ryukyu Islands, May 22, 1940, collected by the author.

Habitat: Found on coral reef.

Dimensions (in $\mathrm{mm}$ ) :

\begin{tabular}{|c|c|}
\hline Holotype & Allotype (ovig. +9 \\
\hline Length of carapace including rostrum $\ldots \ldots \ldots \ldots$ & 3.5 \\
\hline Breadth of carapace & 2.8 \\
\hline Length of rostrum ................................... & 1.2 \\
\hline Breadth of rostrum & 1.0 \\
\hline Length of cheliped ...................................... & 7.0 \\
\hline Length of arm & 2.9 \\
\hline Length of wrist & 1.0 \\
\hline Length of palm & 1.4 \\
\hline Length of movable finger $\ldots \ldots \ldots \ldots \ldots \ldots \ldots \ldots \ldots \ldots \ldots$ & 1.2 \\
\hline
\end{tabular}

3.. Galathea platycheles sp. nov. Text-fig. 5-6.

The carapace is of moderate length and more or less convex laterally. There is no spinule on the upper surface; cervical groove not indicated. The striation are 11 in number as in the Text-fig. 5. The rostrum is of moderate length, and provided with four prominent teeth. Lateral margins of the carapace are equipped with six teeth, exeluding the tooth which forms the outer orbital angle; the second and sixth teeth are very small and faintly indicated.

The first peduncle of the antennule bears three spines on the distal margin. The second peduncle of the antenna is broader than long and equipped with a spinule on both inner and outer angles; the third peduncle is a little longer than broad; the fourth peduncle is small, broader than long. The ischium of the third maxilliped is furnished with an acuminate tooth on inner distal angle; the merus is smooth and furnished with single tooth which is very long, with the tip pointed; the carpus is smooth, provided with three protuberances with two or three long setae. 
The sternum of the third maxilliped is smooth, much protruding upwards; the antero-lateral margin is almost straight; the median sinus is very small.

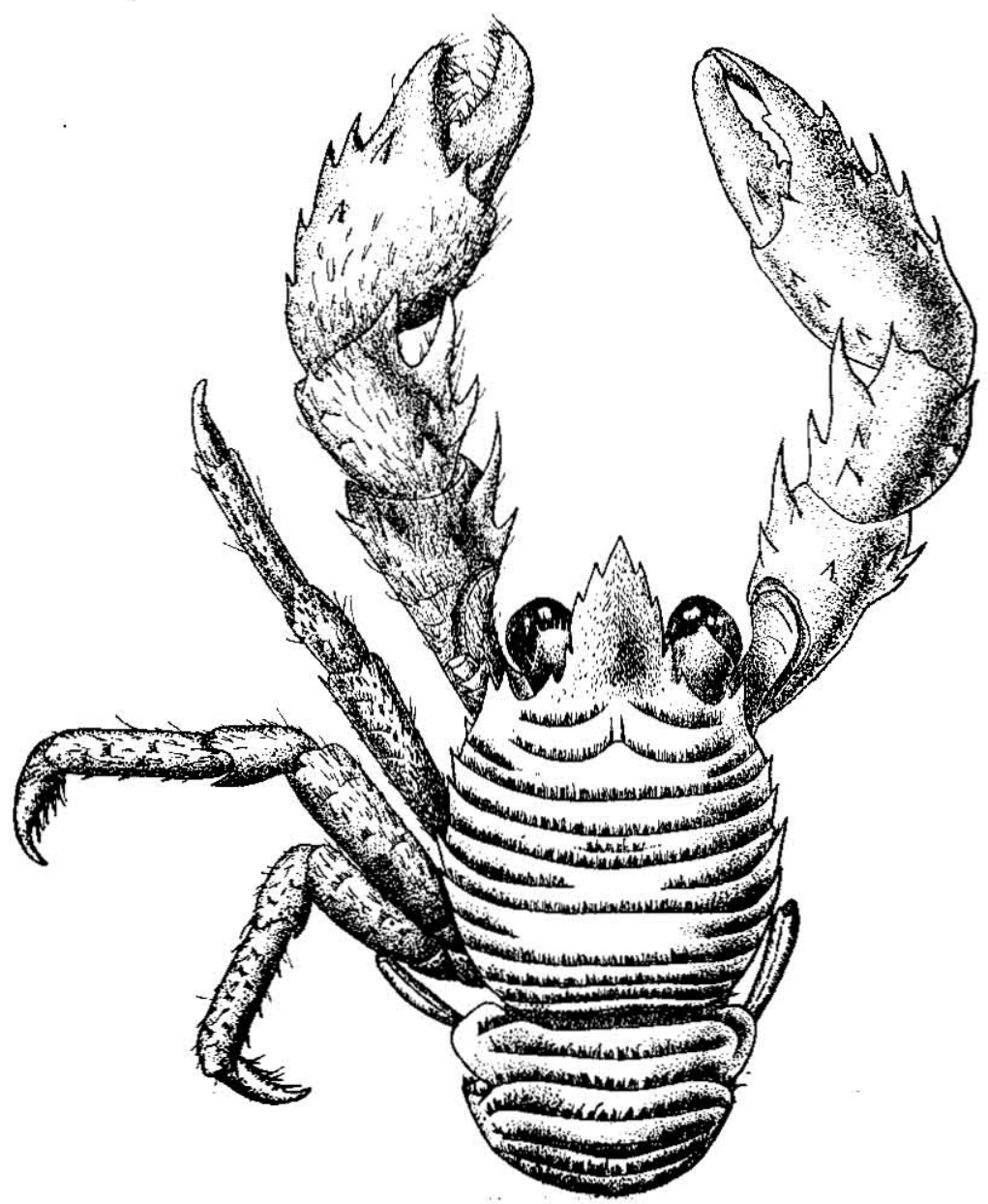

Fig. 5. Galathea platycheles sp. nov.

Holotype (s) from Formosa, $\times 16$.

The chelipeds are rather depressed and short, less than two times as long as the length of the carapace including rostrum in the male, and thickly pubescent, spinulose on the upper surface; the arm is slightly less than two-thirds the length of carapace includ- 
ing rostrum, and equipped with five acuminate teeth: two of them are on inner margin, the distal one very long, which is accompanied by an accessory tooth at the base of. inner side in the right arm only; one tooth is at the middle; the other two teeth are near the outer distal angle. In the right arm, moreover, one small tooth is present behind the outer marginal tooth. The wrist is shorter than the arm, the outer margin expanded and furnished with three teeth, distal one being prominent; inner margin is furnished with three long teeth, of which the middle one is largest; on the dorsal side there are two more teeth at the base of the inner marginal teeth; the palm is very broad and as long as arm, its outer margin being furnished with four or five teeth, two teeth accompanying the outer marginal teeth; while inner margin is equipped with three teeth which are small, but acuminate; the distal margin of the palm is furnished with an acuminate tooth; the movable finger is equipped with a strong tooth near the proximal end of the dorsal face, its cutting margin being equipped with teeth and provided with a tubercle at the base. The immovable finger also has a tubercle near the middle of the cutting margin.

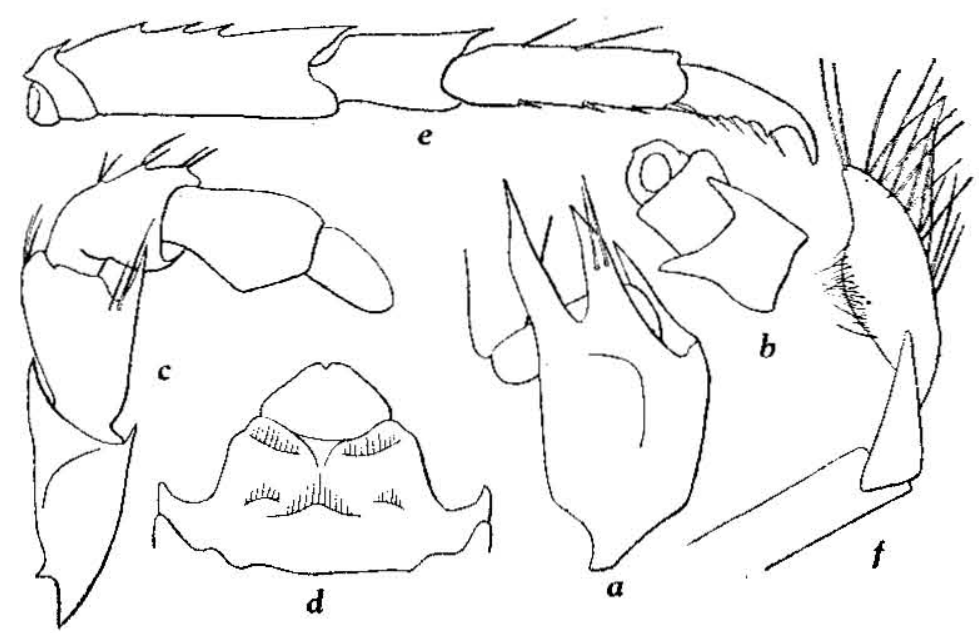

Fig. 6. Galathea platycheles sp. nov.

a : First peduncle of left antennule, $\times 40, b$ : Basal peduncles of right antenna, $\times 40, \mathrm{c}$ : Third maxilliped of right side, $\times 40$, d : Sternum of third maxilliped, $\times 25$, e: Second ambulatory leg, $\times 25, \mathrm{f}:$ Abdominal appendage of male, $\times 75$. 
The ambulatory legs are of moderate length; the merus is a little longer than the propodus, the upper margin is provided with three or four spines, the distal one being prominent; the carpus is about half the length of the merus, the upper distal end greatly protruding into an acuminate tooth; the propodus is somewhat hairy, the posterior margin is provided with three or four spinules; the dactylus is slightly longer than half the propodus, the posterior margin being furnished with four spinules.

The last joint of abdominal appendage in the male is much expanded at the middle, with the tip rounded.

It has some resemblance to Galathea latirostris Dana," Galathea providentia Laurie ${ }^{2)}$ and Galathea ternatensis Melin,"3 in the armature of the rostrum, but it is easily distinguished by the armature of the merus of the third maxilliped.

Types: $\hat{o}$, holotype, ovigerous $\dot{\dagger}$, allotype, Cat. No. 107, Zoological Laboratory, Faculty of Agriculture, Kyushu University; from Swô, Formosa, Nov. 4, 1932, collected by Dr. H. Ohshima.

Habitat: Found on coral reef.

Dimensions (in $\mathrm{mm}$ ) :

\begin{tabular}{|c|c|}
\hline Holotype (i) & Allotype (ovig. f) \\
\hline Length of carapace including rostrum $\ldots . . .3 .0$ & 3.8 \\
\hline 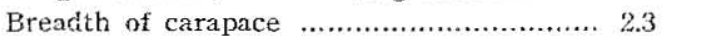 & 3.0 \\
\hline Length of rostrum ............................... 1.0 & 1.3 \\
\hline Breadth of rostrum.............................. 0.9 & 1.1 \\
\hline Length of cheliped .......................... 5.8 & missing \\
\hline Length of arm .................................. 1.8 &, \\
\hline Breadth of arm.................................. 0.9 & " \\
\hline 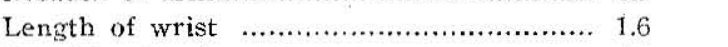 & " \\
\hline Breadth of wrist ............................... 0.9 & $"$ \\
\hline Length of palm................................. 1.8 & $"$ \\
\hline Breadth of palm ............................... 1.3 & , \\
\hline Length of movable finger $\ldots \ldots \ldots \ldots \ldots \ldots \ldots . . . . . . .1 .1$ & $"$ \\
\hline Breadth of movable finger .................... 0.4 & $n$ \\
\hline
\end{tabular}

1) Tana, J. D. 1952 Crustacea:-United States Exploring Expedition; and Atias (1885) : 480, pl. 30, f. 8. Balss, H. 1913 Abh. K. B. Akad, Wiss., Math.-phys. Kl., München, Suppl., 2 (9) : 10-11, f. 9-10.

2) Laurie, R. D. 1926 Trans. Linn. Soc., London, ser. 2, Zool., 19 (1) : 125-128, pl. 8 , f. 1-4.

3) de Man, J. G. 1902 Abh. Senckenb. nat. Ges., Frankfurt a. M., 25 (3) : 714717. Melin, G. 1939 Kungl. Svenska Vetenskap-Akad. Handl., Tredje Ser., Stockholm, 18 (2): $67-72$, f. 39-42. 